\title{
TEACHING PRONUNCIATION USING VARIETIES OF PRONUNCIATION TEACHING MATERIALS AND PRACTICES
}

\author{
Andri Purwanto \\ Program of English Education, Faculty of Language and Art, University of Indraprasta PGRI \\ Jalan Nangka No. 58C Tanjung Barat, Jagakarsa, South Jakarta 12530 \\ purwanto.andri.unindra@gmail.com
}

\begin{abstract}
The objectives of this research are to design varied materials for teaching pronunciation practices with fun and attractive, to introduce the correct spelling in teaching pronunciation and to encourage students in using English as medium of communication. For these reasons, this study was aimed at exploring the pronunciation teaching materials in Pronunciation Practice module and course syllabus at Indraprasta PGRI University, Jakarta. This research tries to measure the output of learning pronunciation with pronunciation practice module which is designed according to Tergujeff's pronunciation teaching materials: namely phonetic training, reading aloud, listen and repeat, rhyme and verse, rules and instructions, awareness-raising activities, spelling and dictation and ear training; and Celce Murcia's Pronunciation teaching materials. This confirms that the creative and dynamic use of current pronunciation teaching materials enable the students not only to undergo accuracy-oriented exercises but also fluency-based activities.
\end{abstract}

Key words: Pronunciation teaching materials, accuracy-oriented exercises, fluency-based activities

\begin{abstract}
ABSTRAK
Tujuan penelitian ini adalah untuk membuat materi yang bervariasi untuk mengajarkan Pronunciation Practice dengan menyenangkan dan menarik untuk memperkenalkan pengejaan yang benar dalam pengajaran Pronunciation, dan untuk memotivasi siswa untuk menggunakan Bahasa Inggris sebagai alat komunikasi. Oleh karena itu, penelitian ini bertujuan untuk menggali materi pembelajaran Pronunciation pada buku modul Pronunciation Practice menurut teori Tergujeff; yaitu pelatihan fonetik, membaca keras, mendengar dan mengulang, rima dan syair, aturan dan perintah, aktivitas peningkat kesadaran, ejaan dan diktasi, serta latihan mendengar; dan juga didasarkan dari teori Celce Murcia. Materi pengajaran Pronunciation yang kreatif dan dinamis memungkinkan siswa tidak hanya merasakan latihan berbasis akurasi berbahasa namun juga aktivitas berbasis kefasihan berbahasa.
\end{abstract}

Kata kunci: materi pengajaran Pronunciation, latihan berbasis akurasi berbahasa, aktivitas berbasis kefasihan berbahasa 


\section{INTRODUCTION}

Secondary school students tend to use dialectical speech patterns or styles when speaking English. Some will not speak out because they are afraid of making mistakes and are embarrassed in expressing their own ideas in English. In the last few decades, pronunciation teaching practices have undergone a significant flux (Jones, 1997). According to Celce-Murcia, et. al. (1996:2), "Western philologists and linguists have studied grammar and vocabulary much longer than pronunciation". For this reason, grammar and vocabulary have been much better understood by most language teachers than pronunciation, which began to be studied systematically shortly before the beginning of the twentieth century.

According to Kelly (2000), the field of modern language teaching has been developed two general approaches to the teaching of pronunciation: an intuitive-imitative approach and an analytic-linguistic approach. Before the late nineteenth century only the first approach was used, occasionally supplemented by the teacher's or textbook writer's impressionistic *and often phonetically inaccurate) observations about sounds based on orthography.

An intuitive-imitative approach depends on the learner's ability to listen to and imitate the rhythms and sounds of the target language without the intervention of any explicit information; it also presupposes the availability first of phonograph records, then of tape recorders and language labs in the midtwentieth century, and more recently of audio- and videocassettes and compact discs.

An analytic-linguistic approach, on the other hand, utilizes information and tools such as a phonetic alphabet, articulatory descriptions, and charts of the vocal apparatus, contrastive information, and other aids to supplement phonic-based listening, imitation, and production. It explicitly informs the learner of and focuses attention on the sounds and rhythms of the target language. This approach was developed to complement rather than to replace the intuitive-imitative approach, which was typically retained as the practice phase used in tandem with the phonetic information.

Different from the previous eras in which pronunciation was neglected in language teaching and learning, teaching pronunciation has been regarded as crucial aspect in Communicative Approach (1998's) (Celce-Murcia et. al., 1996). To illustrate, the primary goal of this method is to promote the importance of communication in language teaching and learning, including pronunciation (Celce-Murcia et. al., 1996).

Currently, the present language methods pay more attention on teaching English pronunciation since the communicative competence and intelligibility have become the primary goals of language teaching (Berns, 1990). Communicative competence refers to the students' ability to foster their language knowledge and usage in a given community through social interaction (Hymes as cited in Brooks, 1992). On the other hand, "intelligibility is interrelated to pronunciation, including stress and rhythm differences" (Berns, 1990:33). Thus, employing language for real communication should be the basis of language pedagogy (Celce-Murcia et. al., 1996).

There are many English training courses teaching speaking but they do not focus on pronunciation. As English teaching has moved to language functions and communicative competencies, a new urgency for the teaching of pronunciation has arisen 
(Celce-Murcia, 1996; Gilbert, 1984). In Indonesia, however, pronunciation has not yet received similar attention. According to my experience, a great number of students have many difficulties in pronunciation. When speaking English, with very little or poorly trained pronunciation skills, they have problems either making themselves understood or understanding others.

Although non-native pronunciation and intonation are not necessarily obstacles to successful communication with English speakers from other parts of the world, too much accented or distorted speech will frequently give rise to misunderstandings, miscommunication and frustration ( $\mathrm{Lu}, 2002)$. Lu insists that incomprehensible nonstandard pronunciation and intonation will produce psychological nervousness in speakers, which is likely to also block their efforts to seek clarification or to paraphrase using alternative expressions with phonetically different pronunciation and intonation. However, $\mathrm{Lu}$ (2002) asserts in his report that it is obvious that this kind of interpretation should take the interlocutors' speech as its basis in face to face spoken interaction. But meanings are blurred, distorted, or buried when pronunciation is grossly unclear or inaccurate.

Pronunciation is a key element of the learning of oral skills in a second language. The role it plays in an English language program varies and the amount of time and effort devoted to it seems to depend to a large degree on the individual teacher. This means that it may or may not form part of regular classroom activity or student self-study. A review of Australian studies of teacher attitudes and practices revealed that pronunciation is an area that some teachers avoid or are reluctant to teach. A study by Brown (2001) suggests that teaching in ESL programs in Australia face some difficulties meeting the pronunciation learning needs of their students, and have indicated that many teachers tend to avoid dealing with pronunciation because they lack confidence, skills and knowledge. In addition to this, this study found that curricula, methodology and the lack of suitable materials, all contributed to inadequacies of teaching and learning in this area, although both students and teachers see the value of intelligible pronunciation in second language learning.

Essentially, the main contribution of this study is to provide informative insights on types of task of pronunciation teaching materials and their impacts on pronunciation teaching and learning. Additionally, the findings of this study offer valuable information on how to select, analyze, design, and evaluate pronunciation teaching materials not only based on intuition but also from empirical findings to meet the needs of actual teaching and learning English pronunciation in such a communicative way.

In the field of English as a Second Language (ESL) the necessity for, and method of teaching pronunciation has become a controversial topic. Many second language educators have varied opinions on the importance of including pronunciation practice within their lesson plans. Classroom activities should cater to what their students consider their most important personal goals or reasons for learning the language. For example, students may wish to build their vocabulary skills or strengthen their testing skills in English. Regardless of current trends or what students may feel their selected needs are, it is safe to say that teaching pronunciation is often considered essential in an ESL class 
where survival skills are imperative to the students' daily lives.

In an ESL setting, the students must not only increase their English comprehension for the classroom, but also need to communicate and interact in English outside the class in various situations. Students need to understand and to be understood. If they cannot hear English well, they are cut off from the language except in printed form. If they cannot be understood easily, they are cut off from conversation with native speakers (Gilbert 1984). In the English as a foreign language (EFL) setting, survival skills play a less important role. English is not necessary for students to communicate with each other.

English is not often used to make friends or to be understood outside of the classroom. It would be easy, therefore, for the teacher to neglect implementing pronunciation tasks in their lessons because they feel there is little or no need for the students to work on that aspect of the language. This attitude denies the students the opportunity to gain precise command of the English language (Gilbert 1984).

The process of learning English is interconnected. This means that each area of the language that is being taught helps improve other aspect of the language. Pronunciation and listening comprehension are linked together by a unified system within which individual sounds are systematically related. Students need this sense of a system in order to make sense of the separate pieces (Gilbert, 1984). If the students' English pronunciation skills are improved, clearly their listening skills and speaking skills become more refined. Spelling skills are also improved when the knowledge of English pronunciation has been increased.

Tomlinson (2012) claims that teaching materials applicable materials ought to embrace five features for leading the teachers and students. Those features are informative (informing the students about the target language), instructional (directing the students to perform the language), experiential (supplying language use experience for students), eliciting (motivating the students to apply the language) and exploratory (facilitating the students to explore the language).

Pronunciation teaching materials are regarded to have paramount roles to shape and reinforce the quality of pronunciation teaching and learning. One of the most widely used instructional media as the containers of language teaching materials in the classrooms is textbooks (e.g. Zacharias, 2005; Tomlinson, 2012; Levis \& Sonsaat, 2016). In this sense, textbooks have been regarded as a focal element in the classroom activities due to its roles to connect the curriculum, teaching materials and teaching learning practices (Zacharias, 2005). Nonetheless, Zacharias (2005) acknowledge that selecting the appropriate materials is not an easy endeavor since both the internationally and locally published textbooks display their prominence.

In response to the inevitable roles of the textbooks in teaching English pronunciation, the teachers seem to strengthen their dependency on them because of their reluctance, skepticism and insufficient training to teach pronunciation (Burgess \& Spencer, 2000; Derwing \& Munro, 2005). These occurred due to a number of factors, such as the dichotomous status of the speakers (e.g. native and non-native), pronunciation as an elusive spoken language sub-skill compared to grammar or vocabulary and uncertain subject for the language teacher (Levis \& Sonsaat, 2016). 
Given these facts, Levis \& Sonsaat (2016) suggest that the design of pronunciation teaching materials should encompass three pivotal principles, namely they should accentuate on intelligibility, they should be integrated with other language skills and they should be able to cater adequate and functional encouragement for the teachers. Specifically, accentuating on intelligibility means that the materials should prioritize the meaningful communication among native speakers (Ns) and non-native speakers (NNs). In the same way, Jenkins (2000) theorizes such a concept as a Lingua Franca Core (LFC) for Ns and NNs communication. Hence, intelligibility-based pronunciation teaching materials should be designed based on those aforementioned views (e.g. pronunciation for communicative purposes and realistic oriented goals).

$\begin{array}{ccc}\text { Despite } & \text { n number of } \\ \text { investigation have } & \text { documented }\end{array}$ pronunciation teaching materials (e.g. Grant, 1995; Gorsuch, 2001; Derwing et. al. 2012; Levis \& Sonsaat, 2016). Tergujeff has offered more specific types of pronunciation teaching materials (Tergujeff, 2010). To illustrate, she classifies pronunciation teaching materials into eight types, namely (1) phonetic training, (2) reading aloud, (3) listen and repeat, (4) rules and instructions, (5) rhyme and verse, (6) awareness-raising activities, (7) spelling and dictation, and (8) ear training.

First, phonetic training is a pronunciation teaching technique applied to enable the students to recognize, understand, practice and internalize the phonetic terminologies. This technique commonly refers to the International Phonetic Alphabet (IPA) as the primary sounds reference (Tergujeff, 2013). In this context, Rasmussen \& Zampini (2010) verbalize that implementing phonetic training generates a variety of benefits, such as increasing the non-native speaker' intelligibility, enlightening the technique how to teach a language skills (e.g. listening skills), supporting the integration between phonetic instruction and L2/FL curriculum, facilitating them to foster their language skills promptly into their immersion environment (target language environment) and mitigating their speaking anxiety when using the target language.

Second, reading aloud (RA) is regarded to be able to provide a valuable pronunciation practice for the students. Gabrielatos (2002) exploring reading aloud as pronunciation practice articulated that I mentioned above that learners may be able to pronounce words correctly while reading aloud. Some teachers might argue then, that RA provides good pronunciation practice. Before addressing this assumption we need to clarify the term 'pronunciation.' The term is sometimes understood by EFL teachers as referring only to the 'correct pronunciation' of individual sounds and words in isolation. Through $\mathrm{RA}$, the students are trained to be able to practice their pronunciation from written to spoken discourse. Conversely, performing pronunciation through RA tends to be misunderstood as the activity to reach accurate pronunciation of individual sounds and isolated words.

Third, listen and repeat is probably considered as one of the oldest pronunciation teaching techniques (Jones, 1997). This technique is assumed to establish the habit formation in acquiring L2 phonology. Technically, the habit formation activities incorporate both cognitive and motor functions to enable the students to produce accurate pronunciation. Nonetheless, a few studies have divulged the limitations of such a technique. 
Next, rules and instructions are inseparable task types in pronunciation teaching materials even though they were absent in L2/ foreign language classroom activities because of the classical misconception (e.g. pronunciation cannot be taught) (Silveira, 2002). However, such as misconception has gradually disappeared currently due to pronunciation instruction does not only embrace linguistic competence but also strategic competence, sociolinguistic competence and discourse competence in terms of underpinning paradigm (Morley as cited in Silveira, 2002).

Subsequently, awarenessraising activities are one of the pronunciation teaching technique emphasizing on generating the ability to accentuate on the sounds of speech showing distinctive meaning (e.g. intonation, rhythm, certain words rhyme and separate sounds) or phonological awareness. Additionally, the students can acquire their L2 based on their L1 patterns. Consequently, they need to deduce their L2 sounds as if they produce their L1. This can minimize the students' mispronunciation (Zimmer, et. al. as cited in Alves \& Margo, 2011).

Spelling and dictation are still viewed as influential task types currently although pronunciation teaching paradigm has shifted from nativeness to intelligibility (Levis, 2005). Deterding \& Mohamad (2016) claim that spelling is still considered to affect pronunciation in the past few decades though people tended to become more literate currently. Furthermore, they explicate that there are four fundamental ways affecting a change of English pronunciation in terms of spelling reflection. Such ways comprise reversion to an original pronunciation; etymologically-based changes; Anglicization of borrowed words; and pronunciation of the letter 'o'.

Last but not the least, ear training is a pronunciation teaching technique utilized to discriminate the individual sounds and familiarize the students with various English accents and other language varieties (Tergujeff, 2013). Even, Cauldwell (2003) metaphorically states that listening and speaking are like two sides of the same coin. Conversely, such a technique is presumed to be a time-consuming and costly attempt (Ashby, 2007).

The field of modern language teaching has developed two general approaches to the teaching of pronunciation: 1 an intuitive-imitative approach and an analytic-linguistic approach. An intuitive-imitative approach depends on the learner's ability to listen to and imitate the rhythms and sounds of the target language without the intervention of any explicit information (without diagram of articulation and pronunciation symbols); it also presupposes the availability of good models to listen to, a possibility that has been enhanced by the availability first of phonograph records, then of tape recorders and language labs in the midtwentieth century, and more recently of audio and videocassettes and compact discs.

An analytic-linguistic approach, on the other hand, utilizes information and tools such as a phonetic alphabet, articulatory descriptions, charts of the vocal apparatus, contrastive information, and other aids to supplement listening, imitation, and production. It explicitly informs the learner of and focuses attention on the sounds and rhythms of the target language. This approach was developed to complement rather than to replace the intuitive-imitative approach, which was typically retained as the practice phase 
used in tandem with the phonetic information.

According to Celce-Murcia (1996), when we look at the various language teaching methods that have had some currency throughout the twentieth century, we must acknowledge that there are methods, such as Grammar Translation and reading-based approaches, in which the teaching of pronunciation is largely irrelevant. In such methods grammar or text comprehension is taught through the medium of the learner's native language and oral communication in the target language is not a primary instructional objective. In the following overview of methods we focus on those methods and approaches for which the teaching and learning of pronunciation is a genuine concern.

The phoneticians involved in this international organization, many of whom had also had experience teaching foreign languages, did much to influence modern language teaching by specifically advocating the following notions and practices: 1) the spoken form of a language is primary and should be taught first, 2) the findings of phonetic should be applied to language teaching, 3 ) teachers must have solid training in phonetics, and 4) learners should be given phonetic training to establish good speech habits.

Furthermore, the teacher often uses a technique derived from the notion of contrast in structural linguistics: the minimal pair drill - drills that use words that differ by a single sound in the same position. This technique, based on the concept of the phoneme as a minimally distinctive sound is used for both listening practice and guided oral production.

Several tools and techniques are critical to the treatment of pronunciation in CLL. First, the audiotape recorder not only captures what is said in the students-generated utterances but also provides a way for students to distance themselves from what was said so they can focus on how it was said and compare their pronunciation with that of the counsellor. Second, the human computer technique, which gives no overt correction of pronunciation, allows the student to initiate pronunciation practice by selecting the items(s) to practice and deciding the amount of repetition needed. In this way, students are able to approximate the target pronunciation to the extent that they desire. Thus the teaching approach is intuitive and imitative as in the Direct Method, but its exact content and the extent to which practice takes place are controlled by the learner/client rather than the teacher or textbook.

We can begin to answer the question of how to teach pronunciation as part of Communicative Approach by reviewing the kinds of techniques and practice materials that have traditionally been used - and are still being used - to teach pronunciation. The following is fairly comprehensive list.

1. Listen and imitate: A technique used in the Direct Method in which students listen to a teacher-provided model and repeat or imitate it. This technique has been enhanced by the use of tape recorders, language labs, and video recorders.

2. Phonetic training: Use of articulatory descriptions, articulatory diagrams, and a phonetic alphabet (a technique from the Reform Movement, which may involve doing phonetic transcription as well as reading phonetically transcribed text).

3. Minimal pair drills: A technique introduced during the Audiolingual era to help students distinguish between similar and problematic sounds in the target language through 
listening discrimination and spoken practice. Minimal pair drills typically begin with word-level drills and then move on to the sentence-level drills (both paradigmatic and syntagmatic drills).

4. Contextualized minimal pairs: In the technique, the teacher establishes the setting (e.g., a blacksmith shoeing a horse) and presents key vocabulary; students are then trained to respond to a sentence stem with the appropriate meaningful response (a or b);

Sentence stem:

The blacksmith (a. hits / b. heats) the horseshoe.

Cued student's response:

a. with the hammer / b. in the fire.

5. Visual Aids: Enhancement of the teacher's description of how sounds are produced by audiovisual aids such as sound-color charts, Fidel wall charts, rods, pictures, mirrors, props, realia, etc. These devices are also used to cue production of the target sounds.

6. Tongue twisters: A technique from speech correction strategies for native speakers (e.g., "She sells seashells by the seashore.")

7. Developmental approximation drills: A technique suggested by firstlanguage acquisition studies in which second language speakers are taught to retrace the steps that many Englishspeaking children follow as they acquire certain sounds in their first language. Thus just as children learning English follow as they acquire /w/ before /r/ or /y/ before /l/, adults who have difficulty producing $/ \mathrm{l} /$ or $/ \mathrm{r} /$ can be encouraged to begin by pronouncing words with initial /w/ or $/ y /$, and then shift to $/ \mathrm{r} /$ or $/ 1 /$, respectively:

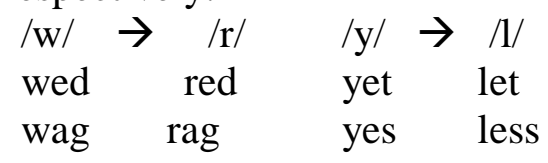

witch rich you Lou

wipe ripe young lung

8. Practice of vowel shifts and stress shifts related by affixation: A technique based on rules of generative phonology used with intermediate or advanced learners. The teacher points out the rule-based nature of vowel and stress shifts in etymologically related words to raise awareness; sentences and shorts texts that contain both members of a pair may be provided as oral practice material:

Vowel shift: street (long i) mimic (short i)

Sentence context: Street mimes often mimic the gestures of passerby.

Stress shift: PHOtograph
photography

Sentence context: I can tell from these photographs that you are very good at photography.

9. Reading aloud/recitation: Passages or scripts for learners to practice and then read aloud, focusing on stress, timing, and intonation. This technique may or may not involve memorization of the text, and it usually occurs with genres that are intended to spoken, such as speeches, poems, plays, and dialogues.

10. Recording of learners' production: Audio and videotapes of rehearsed and spontaneous speeches, free conversation, and role plays. Subsequent playback offers opportunities for feedback from teachers and peers as well as for teacher, peer, and self-evaluation.

\section{METHOD}

This study utilized qualitative research approach and content analysis was selected as the research method. Content analysis enables to examine data as representations of texts, images, observable and interpretable expressions 
for exploring their meanings to supply the researchers new insights and enhance their comprehension on a certain phenomena or notify practical action (Krippendorff, 2004). In addition, document analysis is used as the process of employing documents as a tool to scrutinize social phenomena and examine the individual or institutional records. This involves pronunciation module and course of syllabus used in class to analyze based on the materials development of English pronunciation and Tergujeff's data driven classification (Tergujeff, 2010) including phonetic training, reading aloud, listen and repeat, rhyme and verse, rules and instructions, awareness-raising activities, spelling and dictation and ear training. And communicative approaches based on Celce-Murcia's (1996): listen and imitate, phonetic training, minimal pair drills, contextualized minimal pairs, visual aids, tongue twisters, developmental approximation drills, practice of vowel shifts and stress shifts related by affixation, reading aloud/recitation, recording of learner's production.

\section{RESULTS AND DISCUSSION}

Pronunciation learning materials within the Pronunciation Practice module covered 20 units. Typically, there are theory and practice in every unit in such a module.

\section{Listen and Repeat}

Another major activity frequently appearing in pronunciation specific materials is listen and repeat. This might indicate that although materials for the pronunciation teaching have changed extensively over the past 50 years from focusing on the accurate isolated sounds production to emphasizing on communicative aspects, such as connected speech (Jones, 1997), listen and repeat popularly known as the traditional activity is still widely used in pronunciation learning materials. In the same way, Tergujeff (2010) claims that listen and repeat is probably regarded as all-time favourites in language teaching. Example:

\section{Read Out Loud}

Reading out loud is an activity for students to strengthen their oral production with the correct pronunciation.

$\begin{array}{lll}\text { busy } & \text { business } & \text { building } \\ \text { system } & \text { big } & \text { dinner } \\ \text { Listen } & \text { kitchen } & \text { cinema } \\ \text { ticket } & \text { ship } & \text { lettuce }\end{array}$

\section{Phonetic Training}

(Pronunciation Practice, p.1)

In phonetic training, the lecturer should demonstrate how to sound the phonetic symbol. Lecturer and students are suggested to consult to Oxford dictionary. Before using the pronunciation practice module, students will study how to use the Oxford dictionary. All kinds of phonetic symbols, stress, accents and intonation.

Minimal Pair Drills

In the Pronunciation Practice module, students are trained to differentiate the two sounds through paradigmatic and syntagmatic drills. Example:

\section{Paradigmatic Drills}

- I don't want to - I don't want to sleep. slip.

- That's a high - It's a high hill heel.

- They skied on - They skid on the ice. the ice.

- It was a - It was a terrible scene. terrible sin.

\section{Syntagmatic Drills}

(Pronunciation Practice, p.1)

Don't sit on my seat.

These shoes don't fit my feet. 
Those boys still steal.

You should at least make a list.

(Pronunciation Practice, p.1)

\section{Contextualized Minimal Pairs}

The contextual minimal pairs is a contextual designed sentence in order to practice the students how to differentiate the sound in a sentence. Look at the followings:

Complete these sentences with /iə/ and /ea/ words.

She's got fair $h$

The ch are under the st How many $\mathrm{y}$ have you lived

\section{Tongue Twisters}

In the module of pronunciation practice, students are also trained to practice the tongue twister.

Such as:

She sees many ships by the sea-shore

She saw the shade of a see-saw.

She sells a shell in a sea-shore.

This shoe-brush is sold in a shop.

We share a special moment in Russia.

(Pronunciation Practice 31)

\section{Recording of Learner's Production}

At the end of course, students are demanded to design a teaching tool for pronunciation practice such as, pronunciation drilling on the slides or students reading performances, like story telling or news reading.

\section{Developmental Approximation Drill}

A technique suggested by firstlanguage acquisition studies in which second language speakers are taught to retrace the steps that many Englishspeaking children follow as they acquire certain sounds in their first language.

Which word have / $\Theta /$, and which words have /ð/

1. What are you thinking about?

2. Can I have another?
3. Are you good at maths?

4. Where's the bathroom?

5. What are those things over there?

Words with / / $\quad$ words with /ð/

Thinking

\section{Awareness-Raising Activities}

In the module of pronunciation practice, there are some activities that accentuate on the sound of speech showing distinctive meaning (e.g. intonation, rhythm, certain words rhyme and separate sounds) or phonological awareness. Such as:

Circle the word with the different vowel sound.

1.houses about soup mountains

2.flower town snow brown

In this activity, students are demanded to differentiate the different sound to increase students' phonological awareness.

\section{Spelling and Dictation}

In pronunciation training, the spelling of English words is different from the normal spelling. For example, the word table /t ei bl/ $\square$ tah ei bəl. This will help the students learn pronunciation symbol sound quickly by practicing the sound in the spelling activity. Many students were used to spell the English word with the old way of spelling the English sound such as table $\square$ ti e bi el ii. This way of spelling of the English word is useless and against the real pronunciation sound.

\section{CONCLUSION}

Once the comprehensive analysis was conducted to identify the types of pronunciation teaching materials offered by the Pronunciation Practice Module (course syllabus), the findings dismantled that pronunciation 
course syllabus sufficiently cater the students with the new-fashioned pronunciation teaching materials, such as emphasizing on how to produce accurate English vowels and consonants. Unfortunately, these types of task can only lead the students to produce individual English sounds accurately instead of shaping fluency and integrating pronunciation into authentic communication. This module of pronunciation practice should be administered with communication book such as Speak English like American, even though it's a bit American accent but it gives a little help for the beginners.

\section{REFERENCES}

Alves, U. K., \& Magro, V. (2011). Raising awareness of L2 phonology: Explicit instruction and the acquisition of aspirated /p/ by Brazilian Portuguese speakers. Letras de Hoje, 46(3), 71-80.

Ashby, P. D.S. (2007). Phonetics eartraining-desain and duration. ICPhS XVI. http://www.icphs2007.de/confere nce/Papers/1281/1281.pdf

Berns, M. S. (1990). Contexts of Competence: Social and Cultural Considerations in Communicative Language Teaching. New York: Plenum Press.

Brooks, F. B. (1992). Communicative competence and the conversation course: a social interaction perspective. Linguistics and Education, 4(2) 19-246.

Brown, P. C. (2001). The interactive dictation. The Language Teacher, 25(7), 27-28.

Burgess, J., \& Spencer, S. (2000). Phonology and pronunciation in integrated language teaching and teacher education. System, 28(2), 191-215.
Cauldwell, R. (2003). The two-sides rule in teaching listening and pronunciation. Available at http://www.developingteachers.co $\mathrm{m} /$ articles_tchtraining/two_sides_ richard.htm (retrieved 8 February 2013).

Celce-Murcia, M., et. al. (1996). Teaching Pronunciation: A Reference for Teachers of English to Speakers of Other Languages. Cambridge, England: Cambridge University Press.

Derwing, T. M., \& Munro, M. J. (2005). Second language accent and pronunciation teaching: a research-based approach. TESOL Quarterly, 39(3), 379-397.

Deterding, D., \& Mohamad, N. R. (2016). Spelling pronunciation in English. ELT Journal, 70.

Gabrielatos, C. (2002). Reading loud and clear: reading aloud in ELT. ERIC, $1-10$.

Gorsuch, G. J. (2001). Testing textbook theories and tests: the case of suprasegmentals in a pronunciation textbook. System, 29, 119-136.

Grant, L. (1995). Creating Pronunciation-Based ESL Materials for Publication. In P. Byrd (Ed.), Material Writer's Guide. Boston, MA: Heinle \& Heinle.

Gilbert, J. (1984a). Clear Speech. Pronunciation and Listening Comprehension in American English. Student's Manual and Answer Key. Cambridge: Cambridge University Press.

Gilbert, J. (1984b). Clear Speech. Pronunciation and Listening Comprehension in American English. Teacher's Manual and Answer Key. Cambridge: Cambridge University Press. 
Jenkins, J. (2000). The Phonology of English as an English as an International Language. Oxford, England: Oxford University Press.

Jones, R. H. (1997). Beyond "listen and repeat": Pronunciation teaching materials and theories of second language acquisition. System, 25, 103-112.

Kelly, G. (2000). How To Teach Pronunciation. London: Pearson Education.

Krippendorff, K. (2004). Content Analysis: An Introduction to Its Methodology. 2455 Teller Road Thousand Oaks, California 91320: Sage Publications, Inc.

Levis, J. M. (2005). Changing contexts and shifting paradigms in pronunciation teaching. TESOL Quarterly, 39(3), 369-377.

Levis, J., \& Sonsaat, S. (2016). Pronunciation Materials. In Maryam Azarnoosh, Mitra Zeraatpishe, Akram Faravani \& Hamid Reza Kargozari (eds.). Critical New Literacies: Issues in Materials Development. Rotterdam: Sense Publishers.

Lu, D. (2002). Phonetic symbols: a necessary stepping stone for ESL learners. English Teaching Forum, 40(4), 36-39.

Rasmussen, J., \& Mary, L. Z. (2010). The Effects of phonetics training on the intelligibility and comprehensibility of native Spanish speech by second language learners. In J. Levis \& K. LeVelle (Eds.), Proceedings of the 1st Pronunciation in Second Language Learning and Teaching Conference, Iowa State University, Sept. 2009. (pp. 3852), Ames, IA: Iowa State University.

Silveira, R. (2002). Pronunciation instruction classroom practice and empirical research. Linguagem \& Ensino, 5(1), 93-126.

Tergujeff, E. (2010). Pronunciation teaching materials in Finnish EFL textbooks. In A. Henderson (ed.), English Pronunciation: Issues and Practices (EPIP): Proceedings of the First International Conference, June 3-5 2009, Université de Savoie, Chambéry, France.

(2013). English pronunciation teaching in Finland. The Unpublished Dissertation at the University of Jyvaskyla, Jyvaskyla.

Tomlinson, B. (2012). Materials development for language learning and teaching. Language Teaching, 45, 143-179.

Zacharias, N. T. (2005). Teachers' beliefs about internationallypublished materials: a survey of tertiary English teachers in Indonesia. RELC Journal, 36(1), 23-37. 